УДК 37.091.4:069.12

DOI: 10.37026/2520-6427-2019-99-3-20-23
Юлія ПАВЛЕНКО,

кандидатка педагогічних наук, дочентка кафедри початкової освіти, природничих і математичних дисииплін та методик їх викладання

Полтавського національного педагогічного університету імені В. Г. Короленка

\title{
МУЗЕЙНО-ПЕДАГОГІЧНА СКЛАДОВА В ПРАКТИЦІ ДІЯЛЬНОСТІ ШКОЛИ ВАСИЛЯ СУХОМЛИНСЬКОГО
}

\begin{abstract}
У статті проаналізовано досвід роботи Павлиської школи, а також погляди В. О. Сухомлинського на зміст й особливості організації музейно-педагогічної діяльності в закладі освіти. Розкрито роль шкільного музею та інших форм музейної комунікаціі в освітньому прочесі.

Ключові слова: Василь Сухомлинський, Павлиська школа, середовищний підхід, музейно-педагогічна діяльність, шкільний музей, форми музейної комунікації в закладі освіти.
\end{abstract}

В статье проанализирован опыт работь Павльишской школье, а также взгляды В. О. Сухомлинского относительно содержания и особенностей организации музейно-педагогической деятельности 6 учреждении образования. Раскрыта роль школьного музея и других форм музейной коммуникации в образовательном проиессе.

Ключевые слова: Василий Сухомлинский, Павльишская школа, средовой подход, музейно-педагогическая деятельность, школьный музей, формы музейной коммуникации в учреждении образования.

The proposed article analyzes the experience of the Pavlishskaya School and the views of V. O. Sukhomlinsky on the content and peculiarities of organizing museum-pedagogical activity and thus distinguishes the museum-pedagogical component in the work of the educational institution. In the sphere of implementation of the environmental approach, the specific influence of the museum influence on the student's personality, as well as the understanding of the following concepts: "educational environment», "museum environment», «museum-pedagogical activity», "museum communication», have been rethought. The role of various forms of museum communication in the educational process are revealed. Such as: school museum, exhibitions and expositions, specialized school premises («Ukrainian Word Room», "Reading Room», «Thought Room», «Fairy Tale Room», "Handmade Room», "Music Room», "Corner of the Fine Arts»), collecting storage and archiving of objects valuable in the educational process (children's and non-fiction, record books, musical instruments, educational refinement, music library, music reproductions), individual collectors and others. Through the lens of museum pedagogy, attention is drawn to such essential features of the humanistic model of Sukhomlinsky upbringing as the aesthetization of the educational environment and interactivity in the development of reality. It has been shown how, through purposeful and systematic work, the aesthetic education of students and the professional improvement of teachers are realized, in particular in the organized educational and cultural environment of the school, which has the characteristics of a museum. The progressive ideas of the outstanding head and teacher V. O. Sukhomlinsky, who become the subject of research and new incarnations, in particular at the New Ukrainian School, have been proved once again.

Key words: Vasyl Sukhomlynsky, Pavlishskaya school, educational institution, environmental approach, educational environment, museum, museum environment, museum pedagogy, museum-pedagogical activity, museum communication, forms of museum communication in educational institution, school museum, exhibition, subject room, themed room, workshop, collection, collectibles, aesthetization of the educational environment, aesthetic education, New Ukrainian School.

Постановка проблеми. Глобальні соціальні зміни в Україні спричинюють активний розвиток музейної педагогіки, як наслідок - глибоко переосмислюється освітня функція музеїв, удосконалюється зміст їх діяльності й ведеться пошук на теоретичному й практичному рівнях інноваційних шляхів взаємодії 3 дитячою аудиторією. У школах, дитячих садках, закладах вищої освіти діють різноманітні за масштабом і формою музейні осередки, котрі займають вагоме місце в освітньому процесі. Водночас у світлі нової шкільної реформи й актуалізації середовищного, інтеграційного і діяльнісного підходів практика впровадження різних форм музейної комунікації в закладах освіти набуває особливої актуальності в сучасному українському освітньому просторі.

Аналіз наукових досліджень і публікацій. Виокремлення, комплексний аналіз та подальше впровадження досвіду використання музейного потенціалу в процесі навчання і виховання учнів у славнозвісній Павлиській середній школі, очолюваній В. О. Сухомлинським, є надзвичайно цінним, адже, як справедливо стверджує П. Семиволос, «практично всі магістральні педагогічні нововведення останніх років родом саме 3 Павлиша» [5, с. 8$]$. 
Василь Олександрович Сухомлинський - видатний український педагог, засновник гуманістичної, новаторської педагогіки, кандидат педагогічних наук, член-кореспондент АПН СРСР, прославлений директор Павлиської середньої школи, теоретична, літературно-педагогічна творчість i багатогранна практична діяльність якого відіграла в історії вітчизняної педагогічної думки неабияку роль, збагатила педагогіку України новими положеннями і безцінними ідеями, а величезна педагогічна спадщина стала плідною нивою для наукового вивчення і творчого використання. Дослідженням педагогічної спадщини В. О. Сухомлинського займалися М. Антонець, Л. Бондар, Т. Будняк, В. Бутенко, Д. Гостинна, Н. Дічек, І. Кондицька, В. Кравцов, В. Кремень, Н. Осипчук, Л. Попова, О. Сараєва, П. Семиволос, І. Слюсаренко, О. Соколовська, В. Федяєва, Б. Хижняк, А. Шпортенко, К. Юр'єва та ін.

Педагогічну діяльність щодо втілення музейного компонента в закладі освіти не можна вважати сьогодні новим і малодослідженим явищем. Упродовж кількох останніх десятиріч вивченням питань співпраці музеїв і закладів освіти та особливостей шкільної музейної комунікації займаються вчені як за кордоном, так і в нашій державі (Т. Бєлофастова, О. Ванслова, Л. Гайда, О. Караманов, Г. Ломунова, О. Міхно, В. Петрович, Б. Столяров, О. Топилко, С. Троянська, I. Удовиченко, Л. Шляхтіна, М. Юхневич та ін.). Водночас слід наголосити на тому, що окремих науково-педагогічних досліджень цього аспекту в досвіді школи Василя Сухомлинського не існує, однак слушною є думка О. Міхна: «Творець оригінальної педагогічної системи В. О. Сухомлинський розробив і апробував такі прийоми, методи і форми роботи 3 дітьми, які ми можемо розглядати як пропедевтику музейно-педагогічної діяльності» [4, с. 1].

Мета статті - проаналізувати музейно-педагогічну складову в практиці роботи Павлиської школи та в поглядах В. О. Сухомлинського на основі їх розгляду та вивчення.

Виклад основного матеріалу. Передусім зазначимо, що музейно-педагогічну складову в роботі закладу освіти будемо розглядати у площині середовищного підходу, котрий останнім часом розвивається в педагогіці (А. Андреєв, М. Боритко, К. Дубич, Т. Дубовицька, Н. Карапузова, Л. Капрова, О. Макагон, Ю. Мануйлов, А. Цимбалару, О. Ярошинська та ін.), помітно актуалізувався у філософській Концепції Нової української школи й за своєю суттю є основоположним у реалізації ідеї використання музею як фактора якісних освітніх змін. Також для нашого дослідження важливим $\epsilon$ переосмислення музейного впливу на особистість, яка формується, і розуміння понять «музейно-педагогічна діяльність», «музейна комунікація».

За своєю природою музей у концентрованій формі виражає духовне прагнення минулої і нинішньої культури. Музейне середовище $є$ частиною соціокультурного простору, що має специфічну цінність, естетичну ауру, творчий зміст. Тут кожен предмет - окрема історія, яка володіє величезними резервами для морального, естетичного, патріотичного та інших напрямів виховання. У шкільному музеї, за В. О. Сухомлинським, вирішується багато організаційних та навчально-виховних завдань. I вчитель, і учень, потрапляючи в це особливе середовище та діючи в ньому, переживають емоційний уплив, який призводить до формування позитивних особистісних якостей, розвитку духовної культури.
Під музейно-педагогічною діяльністю ми розуміємо такий вид освітньо-виховної роботи, яка передбачає цілеспрямоване залучення особистості в музейне середовище з метою навчання, виховання й розвитку музейними засобами з урахуванням вікових особливостей, а також організацію освітнього процесу на основі музейних колекцій та культурних цінностей (як у музеї, так і поза ним).

Як слушно зауважує О. Міхно, музейно-педагогічна діяльність спрямована на «формування в дитини ціннісного ставлення до дійсності за допомогою розкриття історико-культурних контекстів матеріальних і нематеріальних реалій навколишнього світу незалежно від їх місця розташування; вона може здійснюватися не тільки в музейному середовищі, а й в іншому просторі - дитячому садку, школі, установі післядипломної освіти, в домашніх умовах, на вулиці, серед живої природи» [4].

Відомий український дослідник у галузі музейної педагогіки О. Караманов влучно зазначає: «Закономірне звернення до освітньої функції музею здійснює справжню «міждисциплінарну революцію», даючи змогу проектувати, розробляти та втілювати в життя найсміливіші музейно-педагогічні програми та проекти, які мають не лише інтегруючий характер, а й по-справжньому дозволяють реалізувати нові навчальні та виховні стратегії, зважаючи на відоме гасло «освіта через діяльність»» [3, с. 35].

Термін «музейна комунікація» у науковий обіг увів відомий канадський музеолог Д. Камерон у 1968 році. За його трактуванням, музейна комунікація - це процес спілкування відвідувача 3 музейними експонатами, що являють собою реальні речі. В основу цього спілкування покладено, з одного боку, вміння творців експозиції вибудовувати за допомогою експонатів особливі невербальні «повідомлення», а 3 іншого - здатність глядача розуміти «мову речей» [9, с. 36].

Услід за Т. Бєлофастовою зауважимо, що така особлива форма комунікації - між музейним предметом і музейною аудиторією - визначає формування особистості, iї цінностей, усього комплексу світогляду. Ця форма спілкування дає можливість сучасному музею реалізовувати свою виховну функцію, здійснювати естетичне, морально-етичне, патріотичне, екологічне та інші види виховання $[1$, с. 36].

В. Федяєва та О. Сараєва послідовно обгрунтували сутність та особливості педагогічної системи В. Сухомлинського й довели системність, цілісність і безперервність організації навчально-виховного процесу у Павлиській середній школі в цілому й системи виховної роботи зокрема, зміст кожного напряму якої (етичне, громадянське, моральне, розумове, трудове, естетичне, фізичне виховання) реалізувався різноманітними шляхами: у процесі вивчення шкільних дисциплін, у позакласній виховній роботі, шляхом залучення учнів до різних видів практичної творчої діяльності, у спільній діяльності сім’і, школи та громадськості [8].

Мистецтво виховання, як стверджував В. О. Сухомлинський, полягає у тому, «щоб виховувати не лише людські відносини, не лише приклад старших, традиції, а й речі - матеріальні й духовні цінності». «Виховання середовищем, обстановкою, речами - одна 3 найтонших сфер педагогічного процесу», - стверджував славетний керівник Павлиської школи [7, с. 93].

На нашу думку, варто ще раз наголосити на прогресивності ідей Василя Сухомлинського, адже в педагогічній науці теорія про освітне середовище й до нині знаходиться на етапі становлення, 
а у своїй авторській школі більше ніж півстоліття тому геніальний педагог успішно його впроваджував на практиці й описував теоретично. Як директор школи Василь Олександрович надавав вагомого значення оформленню навчальних корпусів і особливі вимоги висував до утримання матеріальної бази закладу освіти, адже розглядав іiї як важливий засіб упливу на духовний світ вихованців та необхідну умову для повноцінного педагогічного процесу. На його думку, все, що дитина бачить навколо себе (у коридорі, класі, майстерні тощо), формує іiі духовне обличчя. Тому слід прагнути, «щоб у школі й стіни говорили».

Поняття «освітне середовище», за В. О. Сухомлинським, є досить широким і багатоплановим: «це і світ речей, що оточують дитину, і вчинки старших, i особистий приклад учителя, i загальний моральний тонус життя шкільного колективу» [7, с. 574]. Видатний педагог писав, що для виховання дитини можна використати все, що ії оточує. У контексті таких педагогічних явищ, як «матеріальна база школи», «середовище навчання й виховання учнів та професійної діяльності вчителя», «фактор освітньо-виховного впливу» Василь Олександрович у своїх творах, зокрема «Павлиська середня школа», «Розмова 3 молодим директором», «Народження громадянина», «Проблеми виховання всебічно розвиненої особистості», «Сто порад учителеві», торкається окремих аспектів специфічної діяльності в закладі освіти, яка набуває ознак музейно-педагогічної.

Головним осередком музейно-педагогічної діяльності у школі В. Сухомлинського, безумовно, був шкільний музей, який займав певне місце і до якого ставилися 3 особливою пошаною, адже це не просто кімната, а сховище скарбів, цінних кожному; тут «збирається все, що розуміється й переживається шкільним колективом як честь і гідність школи, що об’єднує всіх у єдину сім'ю» [7, с. 104].

Варто зазначити, що шкільний музей у Павлиші функціонував за безпосередньої участі учнівського колективу. При цьому він був не просто місцем для збору пам'ятних речей і проведення святкових заходів як багато інших шкільних музеїв того часу. Активна діяльність в освоєнні дійсності - істотна ознака моделі виховання В. О. Сухомлинського. У його школі діти активно трудилися як розумово, так і фізично, долучалися до різноманітних видів праці: навчальної та виробничої, індивідуальної і колективної. Майже все в Павлиші створювалося руками дітей за підтримки дорослих, зокрема і шкільний музей.

Елементи музейно-педагогічної комунікації у Павлиській середній школі можна було спостерігати й поза стінами шкільного музею. Так, учні й учителі займалися колекціонуванням «цінних» для школи речей, створювали архіви рукописних журналів, стінгазет, здійснювали анотування та описи своїх зібрань, виготовляли різноманітні стенди та плакати-монтажі, влаштовували цікаві виставки й огляди та активно використовували все зібране в навчально-виховному процесі. Водночас у «Школі під голубим небом» діяло близько вісімдесяти гуртків.

Важливою складовою оригінальної педагогічної системи, створеної видатним генієм, є предметні кабінети, тематичні кімнати, творчі майстерні, як-от: «Кімната Українського Слова», «Кімната для читання», «Кімната думки», «Кімната казки», «Кімната ручної праці», «Музична кімната», «Куточок образотворчих мистецтв» тощо. Кожне з названих спеціалізованих шкільних приміщень не лише відрізнялося своєрідною ошатністю в оформленні, а й виконувало роль «поля» для пізнавальних пошуків, здивувань, відкриттів і творчості. Тут було зосереджено спеціально підібрану дитячу літературу, науково-популярні журнали, музичні інструменти, дослідницьке обладнання, навчальне унаочнення, фонотеку творів класичної і сучасної музики, репродукції картин, матеріали, інструменти й прилади для дитячої праці і творчості - тобто все те, що робить освітній процес змістовним і цікавим. Ми підтримуємо думку О. Міхна про те, що роботу, яка проводилася у спеціалізованих кімнатах, котрі автор порівнює із сучасними «інтерактивними мінімузеями» [4, с. 2], можна вважати пропедевтикою музейно-педагогічної діяльності. Дослідник також наголошує на їі особливій доцільності в умовах сільської школи, що територіально віддалена від самостійно діючих музеїв.

Слід наголосити, що видатний педагог-гуманіст особливого значення надавав естетичному вихованню школярів і вважав, що основним фактором його здійснення $\epsilon$ включення дитини у світ мистецтва. У цьому контексті робота у «Школі радості» здійснювалася через спеціально організовані «сеанси» розглядання картин, створення дітьми власних картинних галерей (збирання репродукцій), оформлення виставок творчих дитячих робіт у «Куточку образотворчих мистецтв».

В. Бутенко, аналізуючи питання, пов'язані із формуванням у молоді естетичного світогляду за В. О. Сухомлинським, стверджує, що в системі виховання дітей та молоді особлива роль належить освітньо-культурному середовищу школи, яке «передбачає широкий спектр позааудиторної роботи, у процесі якої учні можуть реалізувати власні пізнавальні творчі потреби; це створює необхідну умову для гармонізації загального і конкретного, програмного та вибіркового, колективного та індивідуального» [2, с. 134]. У Павлиській школі ця робота була цілеспрямованою і систематичною, оскільки Василь Олександрович турбувався про накопичення у вихованців естетичних вражень, він був переконаний, що вже в дитинстві людина повинна навчитися індивідуально освоювати естетичні цінності. Педагог писав: «Очі - це надзвичайно складний світ думок, почуттів, переживань. Ціла система бесід, пов'язаних із розгляданням картин, у нас була присвячена цьому світові» [6, с. 184].

Насамкінець зазначимо, що вдумливий і турботливий керівник Павлиської середньої школи неабияку увагу приділяв не лише роботі з учнівським, а й 3 учительським колективом, зокрема розробив систему вимог до особистості вчителя та його психолого-педагогічної підготовки. Директор Павлиша хотів бачити серед учителів своєї школи людей високої духовної та професійної культури, у своїх працях він наголошував на необхідності засвоєння теоретичних знань у галузі гуманітарних наук, формування вмінь і навичок художньо-естетичної діяльності. На його думку, така підготовка мала здійснюватися через спеціально організовану освіту вчителів у різних формах роботи учительського колективу школи та їхню самоосвіту, зокрема: читання педагогічної, мистецтвознавчої, науково-популярної літератури, перегляд просвітницьких телепередач, відвідування театрів і музеїв тощо.

Висновки. Отже, зважаючи на аналіз теоретичного матеріалу, можемо стверджувати, що в роботі Павлиської школи вагому роль відігравала музейно-педагогічна складова, яка раніше ретельно не вивчалася, однак має неабияку наукову педагогічну цінність. Ця складова реалізувалася у «Школі радості» через: 
шкільний музей; виставкову й експозиційну діяльність (організація тематичних виставок, оглядів, виготовлення стендів, плакатів-монтажів); спеціалізовані шкільні приміщення (предметні кабінети, тематичні кімнати, творчі майстерні); збирання, зберігання й архівування предметів, цінних в освітньому процесі (дитячої й науково-популярної літератури, самописних видань, музичних інструментів, дослідницького обладнання, навчального унаочнення, фонотеки музичних творів, репродукцій картин, матеріалів, інструментів і приладів для дитячої праці та творчості); колекціонування (створення індивідуальних колекцій учителями, школярами); освіту й самоосвіту педагогів, зокрема й у музеях.

Функціонування шкільного музею й практика інших форм музейної комунікації в очолюваному закладі освіти підтверджує розуміння Василем Сухомлинським освітнього потенціалу музейно-педагогічної діяльності. Прогресивний керівник і вчитель, вкотре випередивши час, реалізував у своїй роботі ті ідеї, які через роки стануть предметом досліджень $і$ нових утілень, зокрема й у Новій українській школі.

\section{СПИСОК ВИКОРИСТАНОЇ ЛІТЕРАТУРИ}

1. Бєлофастова Т. Ю. Музей у системі сучасних комунікацій [Електронний ресурс] / Т. Ю. Бєлофастова // Вісник Державної академії керівних кадрів культури і мистецтва : науковий журнал. - К. : Міленіум. - 2009. - № 4. - C. 36-39. URL: http://archive. nbuv.gov.ua/portal/soc_gum/Vdakk/2009_4/8.pdf (дата звернення: 05.08.2019).

2. Бутенко В. Г. Формування естетичного світогляду молоді в умовах освітньо-культурного середовища школи (з досвіду В. О. Сухомлинського) / В. Г. Бутенко // Педагогічні науки : збірник наукових праць. Херсон : Видавництво ХДУ, 2009. - Вип. 53. C. $132-134$.

3. Караманов О. В. Сучасні тенденції розвитку музейної педагогіки в Україні / О.В.Караманов // Матеріали науково-практичної конференції «Музейна педагогіка - проблеми, сьогодення, перспективи» (Київ, 24-25 вересня 2013 р.) / Національний Києво-Печерський історико-культурний заповідник. К. : НКПІКЗ, 2013. - С. 35-37.

4. Міхно О. Пропедевтика музейно-педагогічної роботи з учнями у спадщині Василя Сухомлинського [Електронний ресурс] / O. Мiхно. URL: lib.iitta.gov. ua/715700/ (дата звернення: 03.08.2019).

5. Семиволос П. Школа, загублена у завтрашньому дні / П. Семиволос // Шкільна бібліотека. - 2008. № 1. - C. 8-9.

6. Сухомлинський В. А. О воспитании / В. А. Сухомлинский. - М. : Политиздат, 1988. - 270 с.

7. Сухомлинський В. О. Вибрані твори : в 5 т. / В. О. Сухомлинський. - Київ : Рад. школа, 1976. $654 \mathrm{c}$.

8. Федяєва В. Л. Педагогічна система В. Сухомлинського : навчально-методичний посібник / В. Л. Федяєва, О. В. Сараєва. - Херсон, 2006. $144 \mathrm{c}$.

9. Cameron D. A viewpoint: the Museum as a Communication System and Implications for Museum Education / D. Cameron // Curator. - 1968. - № 1. P. 33-40.

Дата надходження до редакиї: 09.08.2019 р.

\section{МЕТОДИЧНІ ЗАСАДИ САМОВИХОВАННЯ ЗРОСТАЮЧОЇ ОСОБИСТОСТІ В КОЛЕКТИВІ: РЕТРОСПЕКТИВА ПЕДАГОГІЧНИХ ІДЕЙ ВАСИЛЯ СУХОМЛИНСЬКОГО}

У статті виокремлено й охарактеризовано методичні засади самовиховання зростаючої особистості в учнівсько-педагогічному колективі закладів позашкільної освіти у вільний від навчання в загальноосвітній школі час саме у прочесі педагогічно спрямованого дозвілля. Розкрито провідні ідеї й методичні прийоми, упроваджені В. Сухомлинським у практику з організаиії дозвіллєвої діяльності дітей та учнівської молоді, спрямовані на підвищення якості прочесів виховання, а головне - самовиховання, $i$ які, на нашу думку, найбільш яскраво простежують- ся в діяльності закладів позашкільної освіти. Актуалізовано роль учнівсько-педагогічного колективу як провідного чинника ефективності ичих проиесів.

Ключові слова: методичні засади, методичні прийоми, самовиховання, учнівсько-педагогічний колектив, ідеї В. Сухомлинського, заклад позашкільної освіти, діти, учнівська молодь.

В содержании статьи выделены и охарактеризованы методические принципы самовоспитания растущзей личности в ученическо-педагогическом коллективе 